Prosiding Seminar Nasional Teknologi Informasi dan Kedirgantaraan : Transformasi Teknologi untuk Mendukung Ketahanan Nasional, Yogyakarta, 13 Desember 2018

SENATIK 2018, Vol. IV, ISBN 978-602-52742-0-6

DOI: http://dx.doi.org/10.28989/senatik.v4i0.228

\title{
THE DISTRIBUTION OF AIRCRAFT PASSENGER MOVEMENTS ON JAVA ISLAND USING THE GRAVITY MODEL Gunawan
}

Program Studi Teknik Penerbangan

Sekolah Tinggi Teknologi Adisutjipto (STTA)

Jl. Janti Blok R Lanud Adisutjipto Yogyakarta

Email: guns797@gmail.com

\begin{abstract}
The need for movement always causes problems, especially when humans go to the same destination in a certain area at the same time. It is needed to do the analysis of the distribution of aircraft passenger movement in order to provide the required facilities in the future. This research model the distribution of aircraft passenger movements on Java Island using the Double Constrain Gravity model(DGCR) with the negative exponential, rank and tanner obstacle function. In this case, it is found that the Double Constrain Gravity Model (DGCR) with tanner obstacle function is the best mesthod due to the smallest standard deviation. It could be concluded that the DCGR model with tanner obstacle functions is more accurate when compared to the DCGR model with other obstacle functions in estimating the movement distribution in 2025 on Java Island.
\end{abstract}

\section{Keywords: distribution, movement, model, gravity}

\section{Pendahuluan}

Pergerakan merupakan suatu kegiatan yang rutin dilakukan orang setiap hari untuk memenuhi kebutuhan hidup. Kebutuhan akan pergerakan bersifat sebagai kebutuhan turunan, pergerakan terjadi karena adanya proses pemenuhan kebutuhan yang merupakan kegiatan yang biasa dilakukan setiap hari, seperti halnya pemenuhan kebutuhan akan pekerjaan, pendidikan, kesehatan dan olahraga [1].

Pulau Jawa memiliki wilayah yang luas serta pertumbuhan penduduk yang selalu meningkat setiap tahunnya berdampak pada peningkatan kebutuhan akan alat transportasi. Laju pertumbuhan penduduk mendorong terjadinya peningkatan pada permintaan akan transportasi untuk memenuhi kebutuhan[2]. Transportasi udara merupakan salah satu moda transportasi alternatif untuk menjangkau berbagai wilayah dengan cepat dan tepat. Kelebihan transportasi udara dibandingkan dengan moda transportasi lain yaitu kecepatan lebih tinggi, perjalanan jarak jauh, dan bisa menjangkau daerah lain yang terpencil.

Perkembangan yang terjadi pada masa kini dipengaruhi oleh meningkatnya jumlah penduduk yang begitu signifikan, sehingga memberikan dampak secara langsung pada perencanaan transportasi. Karena dari waktu ke waktu objek yang diangkut selalu bertambah. Adanya pertambahan jumlah penduduk tersebut dengan sendirinya akan membutuhkan pertambahan alat pendukung untuk kegiatan setiap penduduk tesebut. Jika hal ini tidak diantisipasi sejak dini, maka dimasa yang akan datang akan menimbulkan suatu masalah ketidakseimbangan antara kebutuhan transportasi dengan pertumbuhan jumlah penduduk yang ada.

Kebutuhan akan pergerakan selalu menimbulkan permasalahan, khusunya pada saat manusia menuju tujuan yang sama di dalam daerah tertentu pada saat yang bersamaan. Kemacetan, tundaan, polusi suara dan udara adalah beberapa permasalahan yang timbul akibat adanya pergerakan[3]. Di sisi lain bandar udara di pulau jawa sebagian besar merupakan bandar udara dengan pergerakan yang sangat tinggi hal ini ditunjukan dengan adanya nilai indikator konektifitas yang tinggi[4], disamping itu jumlah penerbangan yang 
dilayani oleh bandar udara di pulau jawa juga tinggi[5] . Untuk mengurangi akibat buruk dari peningkatan jumlah pergerakan, maka dilakukan analisis perkiraan pergerakan pada masa yang akan datang, sehingga kita bisa mempersiapkan saranan dan prasarana yang dibutuhkan.

\section{Metodologi Penelitian}

Objek dalam penelitian ini adalah distribusi pergerakan penumpang pada delapan bandar udara di Pulau Jawa, yaitu Bandar Udara International Adisutjipto Yogyakarta (JOG), Bandar Udara International Soekarno-Hatta Tangerang (CGK), Bandar Udara Husein Sastra Negara Bandung (BDO), Bandar Udara International Ahmad Yani Semarang (SRG) dan Bandar Udara International Juanda Surabaya (SUB), Bandar Udara Internasional Halim Perdanakusuma Jakarta (HLM), Bandar Udara Internasional Adi Sumarmo Solo (SOC), Bandar Udara Abdulrahman Saleh Malang(MLG)

Data yang digunakan dalam penelitian tugas akhir ini adalah data sekunder yang diperoleh dari Badan Pusat Statistik (BPS) Indonesia yaitu data penumpang domestik datang dan berangkat di masing-masing bandar udara menuju masing-masing bandar udara tahun 2010-2016 dan menggunakan data yang diperoleh dari website www.treveloka.com untuk informasi aksesibilitas yang berupa biaya harga tiket masing-masing zona kajian digunakan untuk kalibrasi parameter nilai $\beta$ model gravity dengan batasan bangkitan-tarikan (Double Constrain Gravity/DCGR).

Adapun teknik pengolahan data dalam penelitian ini adalah:

a. Perhitungan bangkitan dan tarikan

Untuk menghitung bangkitan dan tarikan di masing-masing bandar udara untuk tahun rencana menggunakan metode trend linear[6] :

$$
\begin{aligned}
& \mathrm{A}=\bar{Y}-\mathrm{B} \cdot \bar{X} \\
& \mathrm{~B}=\frac{\mathrm{N} \sum_{i=1}^{N}\left(X_{i} Y_{i}\right)-\sum_{i=1}^{N}\left(X_{i}\right) \cdot \sum_{i=1}^{N}\left(Y_{i}\right)}{\mathrm{N} \sum_{i=1}^{N}\left(X_{i}{ }^{2}\right)-\left(\sum_{i=1}^{N}\left(X_{i}\right)\right)^{2}} \\
& \mathrm{Y}=\mathrm{A}+\mathrm{B} \cdot \mathrm{X}
\end{aligned}
$$

Dimana :

$\mathrm{Y}=$ jumlah penumpang

$\mathrm{X}=$ banyaknya tahun

$\mathrm{A}=$ konstanta regresi

$\mathrm{B}=$ koefisien regresi

$\bar{Y}=$ nilai rata-rata jumlah penumpang

$\bar{X}=$ nilai rata-rata jumlah banyaknya tahun

b. Analisis Sebaran pergerakan

Untuk analisis sebaran pergerakan menggunakan metode konvensional analogi dan sintetis, untuk metode analogi menggunakan model detroit dan untuk metode sintetis menggunakan model gravity dengan batasan bangkitan-tarikan (Double Constrain Gravity/DCGR).

Model dari metode gravitasi ini mempunyai beberapa hal yang perlu diperhatikan. Dikatakan bahwa pergerakan antara zona asal i dan zona tujuan d berbandi lurus dengan Oi dan Dd dan berbanding terbalik kuadratis terhadap jarak antara kedua kota tersebut. Dalam bentuk matematis model gravity (GR) dinyatakan sebagai berikut[1] :

$$
T_{i d}=O_{i} . D_{d} \cdot f\left(C_{i d}\right)
$$


Untuk model gravity dengan batasan bangkitan-tarikan (Double Constrain Gravity/DCGR) ini rumus yang digunakan adala sebagai berikut [1]:

$$
\begin{aligned}
& T_{i d}=A_{i} \cdot O_{i} \cdot B_{d} \cdot D_{d} \cdot f\left(C_{i d}\right) \\
& A_{i}=\frac{1}{\sum_{d}\left(B_{d} \cdot D_{d} \cdot f_{i d}\right)} \text { untuk seluruh } \mathrm{d} \\
& \boldsymbol{B}_{d}=\frac{1}{\sum_{i}\left(A_{i} \cdot \boldsymbol{O}_{i} \cdot f_{i d}\right)} \text { untuk seluruh } \mathrm{I}
\end{aligned}
$$

Dimana :

$\mathrm{O}_{\mathrm{i}}$ dan $\mathrm{D}_{\mathrm{d}}=$ jumlah pergerakan yang berasal dari zona $\mathrm{i}$ dan yang berakhir di zona d

$\mathrm{A}_{\mathrm{i}}$ dan $\mathrm{B}_{\mathrm{d}}=$ konstanta yang terkait dengan setiap zona bangkitan dan tarikan, dimana konstanta ini disebut sebagai faktor penyeimbang

$f\left(C_{i d}\right) \quad=$ fungsi hambatan atau ukuran aksesibilitas kemudahan) antara zona i dengan zona d

$f\left(C_{i d}\right)$ adalah fungsi hambatan perjalanan yang persamaannya dapat mengambil bentuk sebagai berikut[7]:
a. fungsi eksponensial-negatif
$: f\left(C_{i d}\right)=\exp ^{-\beta C i d}$
b. fungsi pangkat
$\therefore f\left(C_{i d}\right)=C_{i d}^{-\beta}$
$: f\left(C_{i d}\right)=C_{i d}^{-\beta} \cdot \exp ^{-\beta C i d}$

Indikator uji kesesuaian standar deviasi adalah suatu indikator kesalahan yang didasarkan pada total kuadratis dari simpangan antara hasil model dengan hasil observasi yang dapat didefinisikan sebagai persamaan [1]:

$$
S D=\sqrt{\sum_{i=1}^{N} \sum_{d=1}^{N}\left[\frac{\left(\hat{T}_{i d}-T_{i d}\right)^{2}}{N(N-1)-1}\right]}
$$

\section{Hasil dan Pembahasan}

\section{a. Data Bangkitan dan Tarikan}

Berdasarkan data yang diperoleh dari Statistik Transportasi Badan Pusat Statistik (BPS), dapat diketahui jumlah pergerakan penumpang domestik asal dan tujuan tahun 2016. Kemudian di rekpitulasi untuk mendapatkan jumlah bangkitan dan tarikan dari setiap zona dengan cara menjumlahkan masing-masing zona asal dan tujuan. Adapun hasil rekapitulasi bangkitan dan tarikan tahun 2016 adalah sebagai berikut.

Tabel 1. Rekapitulasi bangkitan dan tarikan tahun 2016

Sumber: Badan Pusat Statistik, diolah

\begin{tabular}{|c|c|c|}
\hline Zona & $\begin{array}{c}\text { Bangkitan } \\
\text { Tahun 2016 }\end{array}$ & $\begin{array}{c}\text { Tarikan } \\
\text { Tahun 2016 }\end{array}$ \\
\hline HLP & 1.427 .776 & 1.029 .561 \\
\hline CGK & 4.973 .454 & 6.089 .074 \\
\hline BDO & 214.941 & 428.046 \\
\hline SRG & 1.567 .547 & 1.313 .792 \\
\hline JOG & 1.959 .364 & 1.662 .083 \\
\hline SOC & 875.053 & 763.540 \\
\hline SUB & 3.423 .733 & 3.196 .682 \\
\hline MLG & 430.653 & 389.743 \\
\hline Jumlah & 14.872 .521 & 14.872 .521 \\
\hline
\end{tabular}




\section{b. Pemodelan Bangkitan dan Tarikan}

Dengan menggunakan metode trend linear pada persamaan $(2.1,2.2$ dan 2.3), data historis statistik transportasi penumpang domestik pesawat udara asal dan tujuan pada tabel 1 dapat diramalkan dalam bentuk proyeksi trend. Model hasil peramalan dihitung untuk mendapatkan trip generation 2016 dan 2025. Hasil perhitungan masing-masing zona dapat diketahui total bangkitan dan tarikan hasil pemodelan 2016 pada Tabel 2.

Tabel 2. Bangkitan dan tarikan model 2016

\begin{tabular}{|c|c|c|}
\hline Zona & $\begin{array}{c}\text { Bangkitan Model } \\
\text { Tahun 2016 }\end{array}$ & $\begin{array}{c}\text { Tarikan Model } \\
\text { Tahun 2016 }\end{array}$ \\
\hline HLP & 939.402 & 698.318 \\
\hline CGK & 5.661 .831 & 6.381 .231 \\
\hline BDO & 325.203 & 400.654 \\
\hline SRG & 1.568 .541 & 1.356 .990 \\
\hline JOG & 1.986 .139 & 1.941 .561 \\
\hline SOC & 821.245 & 722.715 \\
\hline SUB & 3.533 .728 & 3.367 .558 \\
\hline MLG & 389.369 & 15.225 .458 \\
\hline Jumlah & 15.225 .458 &
\end{tabular}

Dapat dilihat pada Tabel 2 bahwa jumlah bangkitan dan tarikan model 2016 yaitu 15.225.458 penumpang berbeda dengan jumlah bangkitan dan tarikan 2016 yang sebenarnya yaitu 14.872.521 penumpang. Dari data di atas dapat dihitung galat atau tingkat kesalahan hasil pemodelan dengan data sebenarnya (Tabel 3).

Tabel 3. Perhitungan tingkat kesalahan pada pemodelan bangkitan 2016

\begin{tabular}{|c|c|c|c|}
\hline Zona & $\begin{array}{c}\text { Bangkitan } \\
\text { Tahun 2016 }\end{array}$ & $\begin{array}{c}\text { Bangkitan Model } \\
\text { Tahun 2016 }\end{array}$ & Square Error $^{2}$ \\
\hline HLP & 1.427 .776 & 939.402 & 238.509 .489 .459 \\
\hline CGK & 4.973 .454 & 5.661 .831 & 473.862 .679 .967 \\
\hline BDO & 214.941 & 325.203 & 12.157 .767 .450 \\
\hline SRG & 1.567 .547 & 1.568 .541 & 988.610 \\
\hline JOG & 1.959 .364 & 1.986 .139 & 716.907 .765 \\
\hline SOC & 875.053 & 821.245 & 2.895 .293 .690 \\
\hline SUB & 3.423 .733 & 3.533 .728 & 12.098 .802 .252 \\
\hline MLG & 430.653 & 389.369 & 1.704 .331 .959 \\
\hline \multicolumn{3}{|c|}{ SSE } & 503.436 .771 .694 \\
\hline \multicolumn{3}{|c|}{ Standar Deviasi } & $95.673,38$ \\
\hline
\end{tabular}

Dengan cara yang sama, maka dapat dihitung tingkat kesalahan dari model bangkitan tahun dasar pada Tabel 4. 
Tabel 4. Perhitungan tingkat kesalahan pada pemodelan tarikan 2016

\begin{tabular}{|c|c|c|c|}
\hline Zona & $\begin{array}{c}\text { Tarikan } \\
\text { Tahun 2016 }\end{array}$ & $\begin{array}{c}\text { Tarikan Model } \\
\text { Tahun 2016 }\end{array}$ & Square Error $^{2}$ \\
\hline HLP & 1.029 .561 & 698.318 & 109.721 .763 .108 \\
\hline CGK & 6.089 .074 & 6.381 .231 & 85.355 .712 .649 \\
\hline BDO & 428.046 & 400.654 & 750.346 .013 \\
\hline SRG & 1.313 .792 & 1.356 .990 & 1.866 .096 .003 \\
\hline JOG & 1.662 .083 & 1.941 .561 & 78.107 .952 .484 \\
\hline SOC & 763.540 & 722.715 & 1.666 .720 .543 \\
\hline SUB & 3.196 .682 & 3.367 .558 & 29.198 .637 .754 \\
\hline MLG & 389.743 & 356.432 & 1.109 .653 .811 \\
\hline \multicolumn{3}{|c|}{ SSE } & 503.436 .771 .694 \\
\hline \multicolumn{3}{|c|}{ Standar Deviasi } \\
\hline
\end{tabular}

\section{c. Hasil Peramalan Bangkitan dan Tarikan}

Setelah itu didapat hasil model bangkitan dan tarikan 2025 yang diperoleh dari perhitungan peramalan dengan metode trend linear. Bangkitan dan tarikan hasil peramalan dapat dilihat pada Tabel 5 .

Tabel 5. Bangkitan dan tarikan model hasil peramalan 2025

\begin{tabular}{|c|c|c|}
\hline Zona & $\begin{array}{c}\text { Bangkitan Model } \\
\text { Tahun 2025 }\end{array}$ & $\begin{array}{c}\text { Tarikan Model } \\
\text { Tahun 2025 }\end{array}$ \\
\hline HLP & 2.338 .290 & 1.736 .311 \\
\hline CGK & 8.455 .786 & 9.238 .661 \\
\hline BDO & 613.502 & 832.811 \\
\hline SRG & 2.550 .133 & 2.277 .159 \\
\hline JOG & 3.157 .388 & 3.071 .382 \\
\hline SOC & 1.452 .308 & 1.372 .881 \\
\hline SUB & 5.352 .097 & 5.437 .724 \\
\hline MLG & 716.029 & 668.604 \\
\hline Jumlah & 24.635 .532 & 24.635 .532 \\
\hline
\end{tabular}

\section{d. Perhitungan Trip Distribution dengan Double Constrain Gravity Model (DCGR)}

Dalam penelitian ini menggunakan tiga jenis fungsi hambatan yaitu eksponensialnegatif, pangkat dan tanner. Dari ketiga jenis fungsi hambatan tersebut akan dipilih satu fungsi hambatan yang tepat dengan standar deviasi dengan nilai terkecil. Pada proses perhitungan ini data pergerakan yang digunakan adalah tahun 2016. Setelah terpilih fungsi penghambat yang tepat, maka trip distribution pada tahun peramalan (2025) dapat dilakukan.

\section{1) Kalibrasi Parameter Hambatan}

Kalibrasi ini bertujuan untuk mencari nilai parameter fungsi hambatan gravity yaitu $\beta$. Dengan faktor hambatan pergerakan berupa biaya (harga tiket pesawat udara) dalam rupiah dan waktu tempuh perjalanan dalam menit serta satu set data matriks pergerakan penumpang tahun 2016. Untuk mencari parameter $\beta$ dalam fungsi hambatan dilakukan kalibrasi dengan metode analisiss regresi-linier. Hambatan berupa harga tiket di atas dibuat dalam bentuk matriks biaya yang dipaparkan pada Tabel 6 sedangkan pergerakan penumpang pada tahun 2016 dibuat menjadi data matriks pergerakan tahun 2016 (Tabel 7). 
Tabel 6. Data matriks biaya [Cid]

\begin{tabular}{|c|c|c|c|c|c|c|c|c|}
\hline ZONA & HLP & CGK & BDO & SRG & JOG & SOC & SUB & MLG \\
\hline HLP & - & - & 401.000 & 432.000 & 462.000 & 441.000 & 480.000 & 498.000 \\
\hline CGK & - & - & - & 331.000 & 378.000 & 363.000 & 455.000 & 463.000 \\
\hline BDO & 411.000 & - & - & 615.000 & 703.000 & 1.239 .000 & 455.000 & - \\
\hline SRG & 432.000 & 316.000 & 605.000 & - & - & - & 292.500 & - \\
\hline JOG & 462.000 & 335.000 & 693.000 & - & - & - & 391.000 & - \\
\hline SOC & 441.000 & 335.000 & 1.239 .000 & - & - & - & 638.000 & - \\
\hline SUB & 520.000 & 461.000 & 530.000 & 333.000 & 431.000 & 722.000 & - & - \\
\hline MLG & - & 400.100 & - & - & - & - & - & - \\
\hline
\end{tabular}

Tabel 7. Data matriks pergerakan tahun 2016 [Tid]

\begin{tabular}{|c|c|c|c|c|c|c|c|c|}
\hline ZONA & HLP & CGK & BDO & SRG & JOG & SOC & SUB & MLG \\
\hline HLP & - & - & 1.518 & 217.864 & 307.098 & 192.789 & 537.542 & 170.965 \\
\hline CGK & - & - & - & 914.784 & 1.163 .521 & 524.617 & 2.151 .754 & 218.778 \\
\hline BDO & 295 & - & - & 36.809 & 79.956 & 17.925 & 79.956 & - \\
\hline SRG & 217.054 & 1.097 .188 & 39.684 & - & - & - & 213.621 & - \\
\hline JOG & 92.211 & 1.606 .612 & 85.502 & - & - & - & 175.039 & - \\
\hline SOC & 187.956 & 628.474 & 19.853 & - & - & - & 38.770 & - \\
\hline SUB & 532.045 & 2.326 .147 & 281.489 & 144.335 & 111.508 & 28.209 & - & - \\
\hline MLG & - & 430.653 & - & - & - & - & - & - \\
\hline
\end{tabular}

\section{a) Fungsi Hambatan Eksponensial-negatif}

Dengan menggunakan matriks biaya pada Tabel 6 dan data pergerakan tahun 2016 pada Tabel 7, maka fungsi hambatan eksponensial-negatif (persamaan 2.8) menggunakan biaya dapat dihitung dengan pendekatan metode analisis regresi-linear didapatkan $B$ $=0,000053606$. Sehingga dengan menggunakan parameter $\mathrm{B}=-\beta$, dihasilkan parameter $\beta=-0,000053606$

Setelah parameter $\beta$ diketahui, maka langkah selanjutnya adalah membuat matriks $\exp \left(-\beta C_{i d}\right)$ yaitu mengeksponensialkan hasil perkalian parameter hambatan $\beta$ dengan hambatan berupa harga tiket. Hasil perhitungan dapat dilihat dalam tabel berikut:

Tabel 8. Matriks fungsi hambatan ekponensial-negatif

\begin{tabular}{|c|c|c|c|c|c|c|c|c|}
\hline $\begin{array}{l}\mathrm{Z} \\
\mathrm{O} \\
\mathrm{N} \\
\mathrm{A}\end{array}$ & HLP & CGK & BDO & SRG & JOG & SOC & SUB & MLG \\
\hline $\begin{array}{l}\mathrm{H} \\
\mathrm{L} \\
\mathrm{P}\end{array}$ & - & - & $\begin{array}{c}0,00000000046 \\
162652875041 \\
0000000\end{array}$ & $\begin{array}{c}0,00000000008 \\
761482052627 \\
2500000\end{array}$ & $\begin{array}{c}0,00000000001 \\
754468046080 \\
4200000\end{array}$ & $\begin{array}{c}0,00000000005 \\
408140201873 \\
1000000\end{array}$ & $\begin{array}{c}0,00000000000 \\
668476578124 \\
4420000\end{array}$ & $\begin{array}{c}0,00000000000 \\
254698816828 \\
9960000\end{array}$ \\
\hline $\begin{array}{l}\mathrm{C} \\
\mathrm{G} \\
\mathrm{K} \\
\end{array}$ & - & - & - & $\begin{array}{c}0,00000001967 \\
730823903530 \\
0000000\end{array}$ & $\begin{array}{c}0,00000000158 \\
400073477599 \\
0000000\end{array}$ & $\begin{array}{c}0,00000000353 \\
974058351479 \\
0000000\end{array}$ & $\begin{array}{c}0,00000000002 \\
553365322292 \\
8100000 \\
\end{array}$ & $\begin{array}{c}0,00000000001 \\
662893334278 \\
3200000 \\
\end{array}$ \\
\hline $\begin{array}{l}\mathrm{B} \\
\mathrm{D} \\
\mathrm{O}\end{array}$ & $\begin{array}{c}0,00000000027 \\
007230723101 \\
6000000\end{array}$ & - & - & $\begin{array}{c}0,00000000000 \\
000480996246 \\
7846460\end{array}$ & $\begin{array}{c}0,00000000000 \\
000004299396 \\
4154633\end{array}$ & $\begin{array}{c}0,00000000000 \\
000000000000 \\
0000014\end{array}$ & $\begin{array}{c}0,00000000002 \\
553365322292 \\
8100000\end{array}$ & - \\
\hline $\begin{array}{l}\mathrm{S} \\
\mathrm{R} \\
\mathrm{G} \\
\end{array}$ & $\begin{array}{c}0,00000000008 \\
761482052627 \\
2500000 \\
\end{array}$ & $\begin{array}{c}0,00000004397 \\
255949372610 \\
0000000\end{array}$ & $\begin{array}{c}0,00000000000 \\
000822152519 \\
1594050 \\
\end{array}$ & - & - & & $\begin{array}{c}0,00000015498 \\
401239568100 \\
0000000\end{array}$ & \\
\hline $\begin{array}{c}\mathrm{JO} \\
\mathrm{G}\end{array}$ & $\begin{array}{c}0,00000000001 \\
754468046080 \\
4200000 \\
\end{array}$ & $\begin{array}{c}0,00000001587 \\
966758942120 \\
0000000\end{array}$ & $\begin{array}{c}0,00000000000 \\
000007348829 \\
8868590 \\
\end{array}$ & - & - & - & $\begin{array}{c}0,00000000078 \\
904443862091 \\
8000000 \\
\end{array}$ & - \\
\hline
\end{tabular}




\begin{tabular}{|c|c|c|c|c|c|c|c|}
\hline S & 0,00000000005 & 0,00000001587 & 0,00000000000 & & & & 0,00000000000 \\
O & 408140201873 & 966758942120 & 000000000000 & - & - & 000140177098 \\
C & 1000000 & 0000000 & 0000014 & & & - \\
\hline S & 0,00000000000 & 0,00000000001 & 0,00000000000 & 0,00000001767 & 0,00000000009 & 0,00000000000 & \\
U & 078314716139 & 851085731877 & 045817635600 & 679591697720 & 243972527145 & 000001552627 & \\
B & 7222000 & 7700000 & 9047000 & 0000000 & 1600000 & 0633040 & - \\
\hline M & & 0,0000000048 & & - & & - & - \\
L & - & 444415715642 & - & - & & - \\
G & & 5000000 & & & & - \\
\hline
\end{tabular}

Setelah matriks fungsi hambatan didapatkan, maka selanjutnya menghitung faktor penyeimbang $\left(\mathrm{A}_{\mathrm{i}}\right.$ dan $\left.\mathrm{B}_{\mathrm{d}}\right)$. Dalam perhitungan ini bangkitan dan tarikan yang digunakan adalah bangkitan dan tarikan model 2016. Model yang digunakan adalah $\boldsymbol{A}_{\boldsymbol{i}}=\frac{\mathbf{1}}{\sum_{\boldsymbol{d}}\left(\boldsymbol{B}_{\boldsymbol{d}} \cdot \boldsymbol{D}_{\boldsymbol{d}} \cdot \boldsymbol{f}_{\boldsymbol{i d}}\right)}$ untuk seluruh i $\boldsymbol{B}_{\boldsymbol{d}}=\frac{\mathbf{1}}{\sum_{\boldsymbol{d}}\left(\boldsymbol{A}_{\boldsymbol{i}} \cdot \boldsymbol{o}_{\boldsymbol{i}} \cdot \boldsymbol{f}_{\boldsymbol{i d}}\right)}$ untuk seluruh $\mathbf{d}$. Proses pengulangan nilai $\mathrm{A}_{\mathrm{i}}$ dan $\mathrm{B}_{\mathrm{d}}$ dilakukan secara bergantiandengan nilai awal $\mathrm{A} 1=\mathrm{A} 2=\mathrm{A} 3=\mathrm{A} 4=\mathrm{A} 5=\mathrm{A} 6=\mathrm{A} 7=\mathrm{A} 8=1$ dan dilakukan sampai $A_{i}$ dan $B_{d}$ konvergen (tidak mengalami perubahan lagi). Konvergensi dicapai setelah pengulangan ke-80.

Tabel 9. Faktor penyeimbang DCGR 2016 dengan fungsi hambatan ekponensial-negatif

\begin{tabular}{|c|c|c|}
\hline \multirow{2}{*}{ Zona } & \multicolumn{2}{|c|}{ Faktor Penyeimbang } \\
\cline { 2 - 3 } & $\mathrm{Ai}$ & $\mathrm{Bd}$ \\
\hline HLP & 158,6160 & 5622,8730 \\
\hline CGK & 29,0940 & 188,2547 \\
\hline BDO & 0,9325 & 14,5270 \\
\hline SRG & 0,0080 & 0,1886 \\
\hline JOG & 0,0512 & 3,6463 \\
\hline SOC & 0,0518 & 1,6916 \\
\hline SUB & 32,7949 & 138,3257 \\
\hline MLG & 1,7183 & 320,6448 \\
\hline
\end{tabular}

Setelah nilai faktor penyeimbang dan matriks fungsi hambatan didapatkan, maka untuk mendapatkan nilai pergerakan dari zona asal $i$ dan zona tujuan $d$ dapat dicari dengan persamaan $\mathrm{T}_{\mathrm{id}}=\mathrm{A}_{\mathrm{i}} \cdot \mathrm{O}_{\mathrm{i}} \cdot \mathrm{B}_{\mathrm{d}} \cdot \mathrm{D}_{\mathrm{d}} \cdot \exp \left(-\beta \mathrm{C}_{\mathrm{id}}\right)$. Sehingga menghasilkan matriks akhir seperti yang terlihat pada tabel berikut.

Tabel 10. MAT akhir DCGR 2016 dengan fungsi hambatan ekponensial-negatif

\begin{tabular}{|c|c|c|c|c|c|c|c|c|c|c|c|}
\hline ZONA & HLP & CGK & $\mathrm{BDO}$ & SRG & JOG & SOC & SUB & MLG & oi & Oi & $\mathrm{Ai}$ \\
\hline HLP & - & - & 400.345 & 3.341 & 18.507 & 9.852 & 463.984 & 43.374 & 939.402 & 939.402 & 158,6160 \\
\hline CGK & - & - & - & 829.442 & 1.847 .213 & 712.863 & 1.959 .255 & 313.058 & 5.661 .831 & 5.661 .831 & 29,0940 \\
\hline BDO & 321.596 & - & - & 0 & 0 & 0 & 3.607 & - & 325.203 & 325.203 & 0,9325 \\
\hline SRG & 4.304 & 660.936 & 0 & - & - & - & 903.301 & - & 1.568 .541 & 1.568 .541 & 0,0080 \\
\hline JOG & 7.012 & 1.941 .715 & 0 & - & - & - & 37.412 & - & 1.986 .139 & 1.986 .139 & 0,0512 \\
\hline $\mathrm{SOC}$ & 9.041 & 812.204 & 0 & - & - & - & 0 & - & 821.245 & 821.245 & 0,0518 \\
\hline SUB & 356.364 & 2.577 .007 & 309 & 524.207 & 75.840 & 0 & - & - & 3.533 .728 & 3.533 .728 & 32,7949 \\
\hline MLG & - & 389.369 & - & - & - & - & - & - & 389.369 & 389.369 & 1,7183 \\
\hline dd & 698.318 & 6.381 .231 & 400.654 & 1.356 .990 & 1.941 .561 & 722.715 & 3.367 .558 & 356.432 & 15.225 .458 & & \\
\hline Dd & 698.318 & 6.381 .231 & 400.654 & 1.356 .990 & 1.941 .561 & 722.715 & 3.367 .558 & 356.432 & & 15.225 .458 & \\
\hline $\mathrm{Bd}$ & 5622,8730 & 188,2547 & 14,5270 & 0,1886 & 3,6463 & 1,6916 & 138,3257 & 320,6448 & & & 1,0000000000 \\
\hline
\end{tabular}




\section{b) Fungsi Hambatan Pangkat}

Dengan menggunakan matriks biaya pada Tabel 6 dan data pergerakan tahun 2016 pada Tabel 7, maka fungsi hambatan pangkat (persamaan 2.9) menggunakan biaya dapat dihitung dengan pendekatan metode analisis regresi-linear didapatkan $B=$ $-2,29390867$. Sehingga dengan menggunakan parameter $\mathrm{B}=-\beta$, dihasilkan parameter $\beta=$ 2,293908679

Setelah parameter $\beta$ diketahui, maka langkah selanjutnya adalah membuat matriks $C_{i d}^{-\beta}$ yaitu mempangkatkan paramaeter hambatan $\beta$ ke hambatan berupa harga tiket. Hasil perhitungan dapat dilihat dalam Tabel 11.

Tabel 11. Matriks fungsi hambatan pangkat

\begin{tabular}{|c|c|c|c|c|c|c|c|c|}
\hline $\begin{array}{c}\mathrm{ZON} \\
\mathrm{A}\end{array}$ & HLP & CGK & $\mathrm{BDO}$ & SRG & JOG & SOC & SUB & MLG \\
\hline HLP & - & - & $\begin{array}{c}7.130 .196 .62 \\
1.723,37\end{array}$ & $\begin{array}{c}8.458 .338 .80 \\
6.562,56\end{array}$ & $\begin{array}{c}9.866 .687 .90 \\
5.624,60\end{array}$ & $\begin{array}{c}8.868 .020 .09 \\
3.936,72\end{array}$ & $\begin{array}{c}10.770 .815 .3 \\
83.394,70\end{array}$ & $\begin{array}{c}11.719 .898 .0 \\
99.417,10\end{array}$ \\
\hline CGK & - & - & 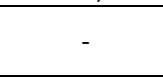 & $\begin{array}{c}4.591 .782 .84 \\
8.901,68\end{array}$ & $\begin{array}{c}6.226 .684 .29 \\
5.511,72\end{array}$ & $\begin{array}{c}5.674 .375 .36 \\
8.455,31\end{array}$ & $\begin{array}{c}9.527 .115 .90 \\
3.373,83\end{array}$ & $\begin{array}{c}9.915 .746 .30 \\
7.989,59\end{array}$ \\
\hline BDO & $\begin{array}{c}7.544 .673 .97 \\
9.440,02\end{array}$ & - & - & $\begin{array}{c}19.017 .388 .1 \\
11.447,80\end{array}$ & $\begin{array}{c}25.845 .299 .2 \\
98.689,40\end{array}$ & $\begin{array}{c}94.830 .742 .6 \\
14.297,00\end{array}$ & $\begin{array}{c}9.527 .115 .90 \\
3.373,83\end{array}$ & - \\
\hline SRG & $\begin{array}{c}8.458 .338 .80 \\
6.562,56\end{array}$ & $\begin{array}{c}4.128 .382 .5 \\
21.042,56\end{array}$ & $\begin{array}{c}18.315 .502 .3 \\
07.898,70\end{array}$ & & - & - & $\begin{array}{c}3.457 .749 .87 \\
8.231,69\end{array}$ & - \\
\hline JOG & $\begin{array}{c}9.866 .687 .90 \\
5.624,60\end{array}$ & $\begin{array}{c}4.720 .067 .7 \\
76.047,79\end{array}$ & $\begin{array}{c}25.009 .710 .1 \\
58.069,70\end{array}$ & - & - & - & $\begin{array}{c}6.728 .880 .23 \\
2.217,13\end{array}$ & - \\
\hline SOC & $\begin{array}{c}8.868 .020 .09 \\
3.936,72\end{array}$ & $\begin{array}{c}4.720 .067 .7 \\
76.047,79\end{array}$ & $\begin{array}{c}94.830 .742 .6 \\
14.297,00\end{array}$ & - & - & - & $\begin{array}{c}20.688 .477 .6 \\
72.652,60\end{array}$ & \\
\hline SUB & $\begin{array}{c}12.941 .650 .8 \\
58.742,20\end{array}$ & $\begin{array}{c}9.817 .766 .7 \\
07.380,56\end{array}$ & $\begin{array}{c}13.519 .670 .2 \\
24.704,00\end{array}$ & $\begin{array}{c}4.655 .676 .08 \\
0.496,40\end{array}$ & $\begin{array}{c}8.413 .492 .49 \\
5.521,38\end{array}$ & $\begin{array}{c}27.475 .735 .3 \\
02.733,70\end{array}$ & 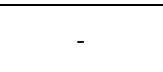 & - \\
\hline $\begin{array}{c}\mathrm{ML} \\
\mathrm{G}\end{array}$ & 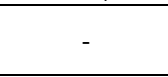 & $\begin{array}{c}7.093 .540 .6 \\
40.866,50\end{array}$ & 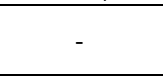 & 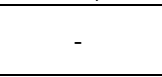 & 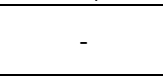 & 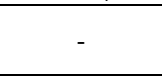 & - & \\
\hline
\end{tabular}

Setelah matriks fungsi hambatan didapatkan, maka selanjutnya menghitung faktor penyeimbang $\left(\mathrm{A}_{\mathrm{i}}\right.$ dan $\left.\mathrm{B}_{\mathrm{d}}\right)$. Dalam perhitungan ini bangkitan dan tarikan yang digunakan adalah bangkitan dan tarikan model 2016 . Model yang digunakan adalah $\boldsymbol{A}_{\boldsymbol{i}}=\frac{\mathbf{1}}{\sum_{\boldsymbol{d}}\left(\boldsymbol{B}_{\boldsymbol{d}} \cdot \boldsymbol{D}_{\boldsymbol{d}} \cdot \boldsymbol{f}_{\boldsymbol{i d}}\right)}$ untuk seluruh i $\boldsymbol{B}_{\boldsymbol{d}}=\frac{\mathbf{1}}{\sum_{\boldsymbol{d}}\left(\boldsymbol{A}_{\boldsymbol{i}} \cdot \boldsymbol{O}_{\boldsymbol{i}} \cdot \boldsymbol{f}_{\boldsymbol{i d}}\right)}$ untuk seluruh d. Proses pengulangan nilai $\mathrm{A}_{\mathrm{i}}$ dan $\mathrm{B}_{\mathrm{d}}$ dilakukan secara bergantiandengan nilai awal $\mathrm{A} 1=\mathrm{A} 2=\mathrm{A} 3=\mathrm{A} 4=\mathrm{A} 5=\mathrm{A} 6=\mathrm{A} 7=\mathrm{A} 8=1$ dan dilakukan sampai $A_{i}$ dan $B_{d}$ konvergen (tidak mengalami perubahan lagi). Konvergensi dicapai setelah pengulangan ke-60.

Tabel 12. Faktor penyeimbang DCGR 2016 dengan fungsi hambatan pangkat

\begin{tabular}{|c|c|c|}
\hline \multirow{2}{*}{ Zona } & \multicolumn{2}{|c|}{ Faktor Penyeimbang } \\
\cline { 2 - 3 } & $\mathrm{Ai}$ & $\mathrm{Bd}$ \\
\hline HLP & 1,848099 & 0,0000000000000000000194459 \\
\hline CGK & 2,689799 & 0,0000000000000000000322631 \\
\hline BDO & 0,742177 & 0,0000000000000000000070786 \\
\hline SRG & 0,927972 & 0,0000000000000000000104540 \\
\hline JOG & 0,772123 & 0,0000000000000000000077007 \\
\hline SOC & 0,579597 & 0,0000000000000000000061430 \\
\hline SUB & 0,392285 & 0,0000000000000000000052277 \\
\hline MLG & 0,684742 & 0,0000000000000000000058358 \\
\hline
\end{tabular}

Setelah nilai faktor penyeimbang dan matriks fungsi hambatan didapatkan, maka untuk mendapatkan niai pergerakan dari zona asal i dan zona tujuan d dapat dicari dengan 
persamaan $\mathrm{T}_{\mathrm{id}}=\mathrm{A}_{\mathrm{i}} \cdot \mathrm{O}_{\mathrm{i}} \cdot \mathrm{B}_{\mathrm{d}} \cdot \mathrm{D}_{\mathrm{d}} \cdot C_{i d}^{-\beta}$. Sehingga menghasilkan matriks akhir seperti yang terlihat pada Tabel 13 .

Tabel 13. MAT akhir DCGR 2016 dengan fungsi hambatan pangkat

\begin{tabular}{|c|c|c|c|c|c|c|c|c|c|c|c|}
\hline ZONA & HLP & CGK & BDO & SRG & JOG & SOC & SUB & MLG & oi & Oi & $\mathrm{Ai}$ \\
\hline HLP & & & 35.107 & 208.314 & 256.112 & 68.352 & 329.194 & 42.323 & 939.402 & 939.402 & 1,848099 \\
\hline CGK & & & & 992.009 & 1.417 .803 & 383.654 & 2.554 .256 & 314.108 & 5.661 .831 & 5.661 .831 & 2,689799 \\
\hline SRG & 167.185 & 1.237 .146 & 75.607 & & & & 88.603 & & 1.568 .541 & 1.568 .541 & 0,927972 \\
\hline JOG & 205.470 & 1.490 .234 & 108.773 & & & & 181.662 & & 1.986 .139 & 1.986 .139 & 0,772123 \\
\hline SUB & 243.616 & 2.801 .934 & 53.151 & 91.554 & 174.379 & 169.094 & & & 3.533 .728 & 3.533 .728 & 0,392285 \\
\hline MLG & & 389.369 & & & & & & & 389.369 & 389.369 & 0,684742 \\
\hline $\mathrm{dd}$ & 698.318 & 6.381 .231 & 400.654 & 1.356 .990 & 1.941 .561 & 722.715 & 3.367 .558 & 356.432 & 15.225 .458 & & \\
\hline Dd & 698.318 & 6.381 .231 & 400.654 & 1.356 .990 & 1.941 .561 & 722.715 & 3.367 .558 & 356.432 & & 15.225 .458 & \\
\hline
\end{tabular}

\section{d) Fungsi Hambatan Tanner}

Dengan menggunakan matriks biaya pada Tabel 6 dan data pergerakan tahun 2016 pada Tabel 7, maka fungsi hambatan tanner (persamaan 2.10) menggunakan biaya dapat dihitung dengan pendekatan metode analisis regresi-linear didapatkan $B=$ $-0,00000342$. Sehingga dengan menggunakan parameter $\mathrm{B}=-\beta$, dihasilkan parameter $\beta=0,000003421$

Setelah parameter $\beta$ diketahui, maka langkah selanjutnya adalah membuat matriks $C_{i d}^{-\beta} \cdot \exp \left(-\beta C_{i d}\right)$. Hasil perhitungan dapat dilihat dalam Tabel 14.

Tabel 14. Matriks fungsi hambatan tanner

\begin{tabular}{|c|c|c|c|c|c|c|c|c|}
\hline ZONA & HLP & CGK & BDO & SRG & JOG & SOC & SUB & MLG \\
\hline HLP & - & - & 3,942463672 & 4,383521931 & 4,857278433 & 4,520579685 & 5,165767853 & 5,493849644 \\
\hline CGK & - & - & - & 3,102925954 & 3,644160506 & 3,461884539 & 4,742347522 & 4,873922953 \\
\hline BDO & 4,079663178 & - & - & 8,197831246 & 11,077378757 & 69,302691321 & 4,742347522 & - \\
\hline SRG & 4,383521931 & 2,947721746 & 7,922137534 & - & - & - & 2,720028325 & - \\
\hline JOG & 4,857278433 & 3,145676505 & 10,704845710 & - & - & - & 3,809878192 & - \\
\hline SOC & 4,520579685 & 3,145676505 & 69,302691321 & - & - & - & 8,868887457 & - \\
\hline SUB & 5,923266758 & 4,840690754 & 6,129398983 & 3,124228108 & 4,368552136 & 11,821280744 & - & - \\
\hline MLG & - & 3,930344381 & - & - & - & & - \\
\hline
\end{tabular}

Setelah matriks fungsi hambatan didapatkan, maka selanjutnya menghitung faktor penyeimbang $\left(\mathrm{A}_{\mathrm{i}}\right.$ dan $\left.\mathrm{B}_{\mathrm{d}}\right)$. Dalam perhitungan ini bangkitan dan tarikan yang digunakan adalah bangkitan dan tarikan model 2016 . Model yang digunakan adalah $\boldsymbol{A}_{\boldsymbol{i}}=\frac{\mathbf{1}}{\sum_{\boldsymbol{d}}\left(\boldsymbol{B}_{\boldsymbol{d}} \cdot \boldsymbol{D}_{\boldsymbol{d}} \cdot \boldsymbol{f}_{\boldsymbol{i d}}\right)}$ untuk seluruh i $\boldsymbol{B}_{\boldsymbol{d}}=\frac{1}{\sum_{\boldsymbol{d}}\left(\boldsymbol{A}_{\boldsymbol{i}} \cdot \boldsymbol{O}_{\boldsymbol{i}} \cdot \boldsymbol{f}_{\boldsymbol{i} \boldsymbol{d}}\right)}$ untuk seluruh d. Proses pengulangan nilai $\mathrm{A}_{\mathrm{i}}$ dan $\mathrm{B}_{\mathrm{d}}$ dilakukan secara bergantian dengan nilai awal $\mathrm{A} 1=\mathrm{A} 2=\mathrm{A} 3=\mathrm{A} 4=\mathrm{A} 5=\mathrm{A} 6=\mathrm{A} 7=\mathrm{A} 8=1$ dan dilakukan sampai $A_{i}$ dan $B_{d}$ konvergen (tidak mengalami perubahan lagi). Konvergensi dicapai setelah pengulangan ke-61. 
Tabel 15. Faktor penyeimbang DCGR 2016 fungsi hambatan tanner

\begin{tabular}{|c|c|c|}
\hline \multirow{2}{*}{ Zona } & \multicolumn{2}{|c|}{ Faktor Penyeimbang } \\
\cline { 2 - 3 } & $\mathrm{Ai}$ & $\mathrm{Bd}$ \\
\hline HLP & 1,990777 & 0,000000041 \\
\hline CGK & 2,554567 & 0,000000056 \\
\hline BDO & 0,764743 & 0,000000014 \\
\hline SRG & 0,755245 & 0,000000017 \\
\hline JOG & 0,682836 & 0,000000014 \\
\hline SOC & 0,505810 & 0,000000011 \\
\hline SUB & 0,451872 & 0,000000011 \\
\hline MLG & 0,713137 & 0,000000012 \\
\hline
\end{tabular}

Setelah nilai faktor penyeimbang dan matriks fungsi hambatan didapatkan, maka untuk mendapatkan nilai pergerakan dari zona asal i dan zona tujuan d dapat dicari dengan persamaan $\mathrm{T}_{\mathrm{id}}=\mathrm{A}_{\mathrm{i}} \cdot \mathrm{O}_{\mathrm{i}} \cdot \mathrm{B}_{\mathrm{d}} \cdot \mathrm{D}_{\mathrm{d}} \cdot C_{i d}^{-\beta} \cdot \exp \left(-\beta C_{i d}\right)$. Sehingga menghasilkan matriks akhir seperti yang terlihatpada tabel berikut.

Tabel 16. MAT akhir DCGR 2016 dengan fungsi hambatan tanner

\begin{tabular}{|c|c|c|c|c|c|c|c|c|c|c|c|}
\hline ZONA & HLP & CGK & $\mathrm{BDO}$ & SRG & JOG & SOC & SUB & MLG & oi & $\mathrm{Oi}$ & $\mathrm{Ai}$ \\
\hline HLP & - & - & 42.290 & 185.083 & 246.592 & 64.562 & 355.534 & 45.340 & 939.402 & 939.402 & 1,990777 \\
\hline CGK & - & - & - & 1.013 .246 & 1.430 .818 & 382.379 & 2.524 .296 & 311.091 & 5.661 .831 & 5.661 .831 & 2,554567 \\
\hline $\mathrm{BDO}$ & 29.361 & - & - & 46.030 & 74.786 & 131.622 & 43.405 & - & 325.203 & 325.203 & 0,764743 \\
\hline SRG & 150.274 & 1.245 .852 & 53.830 & - & - & - & 118.585 & - & 1.568 .541 & 1.568 .541 & 0,755245 \\
\hline JOG & 190.633 & 1.522 .078 & 83.273 & - & - & - & 190.156 & - & 1.986 .139 & 1.986 .139 & 0,682836 \\
\hline SOC & 54.342 & 466.199 & 165.123 & & - & - & 135.582 & - & 821.245 & 821.245 & 0,505810 \\
\hline SUB & 273.708 & 2.757 .733 & 56.139 & 112.632 & 189.365 & 144.152 & - & - & 3.533 .728 & 3.533 .728 & 0,451872 \\
\hline MLG & - & 389.369 & - & - & - & - & - & - & 389.369 & 389.369 & 0,713137 \\
\hline $\mathrm{dd}$ & 698.318 & 6.381 .231 & 400.654 & 1.356 .990 & 1.941 .561 & 722.715 & 3.367 .558 & 356.432 & 15.225 .458 & & \\
\hline Dd & 698.318 & 6.381 .231 & 400.654 & 1.356 .990 & 1.941 .561 & 722.715 & 3.367 .558 & 356.432 & & 15.225 .458 & \\
\hline $\mathrm{Bd}$ & 0,000000041 & 0,000000056 & 0,000000014 & 0,000000017 & 0,000000014 & 0,000000011 & 0,000000011 & 0,000000012 & & & 1,0000000000 \\
\hline
\end{tabular}

\section{2) Uji Kesesuaian Matriks}

Untuk mendapatkan model DCGR terbaik, maka dilakukan uji kesesuaian matriks dengan perhitungan SD. Dari Tabel 10, 13 dan 16 didapatkan data penumpang hasil pemodelan DCGR dengan fungsi hambatan eksponensial-negatif, pangkat dan tanner yang digunakan untuk mencari nilai SD.

Dari hasil perhitungan dapat dilihat perbandingan nilai SD dari ketiga jenis fungsi hambatan yang akan digunakan sebagai pemodelan trip distribution penumpang tahun 2016 . Adapun rekapitulasi perbandingan nilai SD dapat dilihat pada Tabel 17.

Tabel 17. Rekapitulasi nilai SD fungsi hambatan model DCGR

\begin{tabular}{|c|l|c|}
\hline No & \multicolumn{1}{|c|}{ Model DCGR } & SD \\
\hline 1 & Fungsi Hambatan Eksponensial-negatif & $202.886,81$ \\
\hline 2 & Funsgi Hambatan Pangkat & $126.587,76$ \\
\hline 3 & Fungsi Hambatan Tanner & $119.785,65$ \\
\hline
\end{tabular}


Dari kegita jenis fungsi hambatan tersebut seperti yang sudah dihitung di atas, diperoleh model DCGR dengan fungsi hambatan tanner merupakan model terbaik dengan nilai SD terkecil. Karena semakin besar nilai SD, maka semakin tidak akurat MAT hasil penaksiran dibandingkan MAT hasil pengamatan.

\section{3) Trip Distribution Dengan Model DCGR Tahun 2025}

Model trip distribution penumpang tahun 2025 dapat dicari dengan menggunakan model yang telah dibuat sebelumnya, sesuai dengan menggunakan metode analisiss regresilinear. Maka model DCGR dengan fungsi hambatan tanner merupakan model terbaik yang akan digunakan.

Setelah didapatkan bangkitan dan tarikan tahun 2025 hasil peramalan dengan metode trend linear. maka dapat dilakukan perhitungan. Untuk menghitung trip distribution dengan menggunakan model yang sudah dibuat sebelumnya, maka masing-masing matriks fungsi hambatan dikalibrasi ulang menggunakan bangkitan dan tarikan tahun 2025 untuk menghitung faktor penyeimbang $A_{i}$ dan $B_{d}$ tahun ramalan 2025. Perhitungan koefisien penyeimbang dilakukan sampai $A_{i}$ dan $B_{d}$ konvergen. Konvergensi dicapai setelah pengulangan ke-57.

Tabel 18. Koefisien Penyeimbang tahun ramalan 2025 Fungsi Hambatan Tanner untuk hambatan biaya

\begin{tabular}{|c|c|c|}
\hline \multirow{2}{*}{ Zona } & \multicolumn{2}{|c|}{ Faktor Penyeimbang } \\
\cline { 2 - 3 } & $\mathrm{Ai}$ & $\mathrm{Bd}$ \\
\hline HLP & 1,838001 & 0,0000000249 \\
\hline CGK & 2,367843 & 0,0000000330 \\
\hline BDO & 0,657794 & 0,0000000080 \\
\hline SRG & 0,801971 & 0,0000000108 \\
\hline JOG & 0,720079 & 0,0000000091 \\
\hline SOC & 0,509465 & 0,0000000068 \\
\hline SUB & 0,480113 & 0,0000000072 \\
\hline MLG & 0,834304 & 0,0000000083 \\
\hline
\end{tabular}

Setelah nilai faktor penyeimbang dan matriks fungsi hambatan (Tabel 18) didapatkan, maka untuk mendapatkan niai pergerakan dari zona asal i dan zona tujuan $\mathrm{d}$ dapat dicari dengan persamaan $\mathrm{T}_{\mathrm{id}}=\mathrm{A}_{\mathrm{i}} \cdot \mathrm{O}_{\mathrm{i}} \cdot \mathrm{B}_{\mathrm{d}} \cdot \mathrm{D}_{\mathrm{d}} \cdot C_{i d}^{-\beta} \cdot \exp \left(-\beta C_{i d}\right)$. Sehingga menghasilkan matriks akhir seperti yang terlihat pada Tabel 19.

Tabel 19. MAT akhir model DCGR tahun 2025 Fungsi Hambatan Tanner

\begin{tabular}{|c|c|c|c|c|c|c|c|c|c|c|c|}
\hline $\begin{array}{c}\mathrm{ZON} \\
\mathrm{A}\end{array}$ & HLP & CGK & BDO & SRG & JOG & SOC & SUB & MLG & oi & Oi & $\mathrm{Ai}$ \\
\hline HLP & - & - & 113.331 & 464.780 & 585.355 & 181.343 & 863.224 & 130.256 & $\begin{array}{c}2.338 .29 \\
0\end{array}$ & $\begin{array}{c}2.338 .29 \\
0\end{array}$ & 1,838001 \\
\hline CGK & - & - & - & 1.532 .704 & 2.045 .911 & 646.965 & 3.691 .858 & 538.348 & $\begin{array}{c}8.455 .78 \\
6\end{array}$ & $\begin{array}{c}8.455 .78 \\
6\end{array}$ & 2,367843 \\
\hline BDO & 71.075 & - & - & 81.618 & 125.350 & 261.046 & 74.412 & - & 613.502 & 613.502 & 0,657794 \\
\hline SRG & 387.018 & 1.838 .455 & 108.368 & - & - & - & 216.292 & - & $\begin{array}{c}2.550 .13 \\
3\end{array}$ & $\begin{array}{c}2.550 .13 \\
3\end{array}$ & 0,801971 \\
\hline JOG & 476.747 & 2.181 .058 & 162.790 & - & - & - & 336.794 & - & $\begin{array}{c}3.157 .38 \\
8\end{array}$ & $\begin{array}{c}3.157 .38 \\
8\end{array}$ & 0,720079 \\
\hline SOC & 144.395 & 709.794 & 342.974 & - & - & - & 255.145 & - & $\begin{array}{c}1.452 .30 \\
8\end{array}$ & $\begin{array}{c}1.452 .30 \\
8\end{array}$ & 0,509465 \\
\hline SUB & 657.076 & 3.793 .324 & 105.347 & 198.057 & 314.766 & 283.526 & - & - & $\begin{array}{c}5.352 .09 \\
7\end{array}$ & $\begin{array}{c}5.352 .09 \\
7\end{array}$ & 0,480113 \\
\hline MLG & - & 716.029 & - & - & - & - & - & - & 716.029 & 716.029 & 0,834304 \\
\hline $\mathrm{dd}$ & 1.736 .311 & 9.238 .661 & 832.811 & 2.277 .159 & 3.071 .382 & 1.372 .881 & 5.437 .724 & 668.604 & $\begin{array}{c}24.635 .5 \\
32\end{array}$ & & \\
\hline $\mathrm{Dd}$ & 1.736 .311 & 9.238 .661 & 832.811 & 2.277.159 & 3.071 .382 & 1.372 .881 & 5.437 .724 & 668.604 & & $\begin{array}{c}24.635 .5 \\
32\end{array}$ & \\
\hline $\mathrm{Bd}$ & $\begin{array}{c}0,00000002 \\
49\end{array}$ & $\begin{array}{c}0,00000003 \\
30\end{array}$ & $\begin{array}{c}0,00000000 \\
80\end{array}$ & $\begin{array}{c}0,00000001 \\
08\end{array}$ & $\begin{array}{c}0,00000000 \\
91\end{array}$ & $\begin{array}{c}0,00000000 \\
68\end{array}$ & $\begin{array}{c}0,00000000 \\
72\end{array}$ & $\begin{array}{c}0,00000000 \\
83\end{array}$ & & & $\begin{array}{c}1,00000000 \\
00\end{array}$ \\
\hline
\end{tabular}


Sehingga distribusi penumpang yang diramalkan oleh model gravity dengan batasan bangkitan dan tarikan (double constrain/DCGR) untuk tahun 2025 ditunjukan dalam Tabel 20.

Tabel 20. Trip distribution penumpang model DCGR tahun 2025 Fungsi Hambatan Tanner

\begin{tabular}{|c|c|c|c|c|c|c|c|}
\hline \multirow{2}{*}{ No } & \multicolumn{2}{|c|}{ Zona } & Penumpang & \multirow{2}{*}{ No } & \multicolumn{2}{|c|}{ Zona } & Penumpang \\
& Asal & Tujuan & Model 2025 & & Asal & Tujuan & Model 2025 \\
\hline 1 & HLP & BDO & 113.331 & 19 & SRG & BDO & 108.368 \\
\hline 2 & HLP & SRG & 464.780 & 20 & SRG & SUB & 216.292 \\
\hline 3 & HLP & JOG & 585.355 & 21 & JOG & HLP & 476.747 \\
\hline 4 & HLP & SOC & 181.343 & 22 & JOG & CGK & 2.181 .058 \\
\hline 5 & HLP & SUB & 863.224 & 23 & JOG & BDO & 162.790 \\
\hline 6 & HLP & MLG & 130.256 & 24 & JOG & SUB & 336.794 \\
\hline 7 & CGK & SRG & 1.532 .704 & 25 & SOC & HLP & 144.395 \\
\hline 8 & CGK & JOG & 2.045 .911 & 26 & SOC & CGK & 709.794 \\
\hline 9 & CGK & SOC & 646.965 & 27 & SOC & BDO & 342.974 \\
\hline 10 & CGK & SUB & 3.691 .858 & 28 & SOC & SUB & 255.145 \\
\hline 11 & CGK & MLG & 538.348 & 29 & SUB & HLP & 657.076 \\
\hline 12 & BDO & HLP & 71.075 & 30 & SUB & CGK & 3.793 .324 \\
\hline 13 & BDO & SRG & 81.618 & 31 & SUB & BDO & 105.347 \\
\hline 14 & BDO & JOG & 125.350 & 32 & SUB & SRG & 198.057 \\
\hline 15 & BDO & SOC & 261.046 & 33 & SUB & JOG & 314.766 \\
\hline 16 & BDO & SUB & 74.412 & 34 & SUB & SOC & 283.526 \\
\hline 17 & SRG & HLP & 387.018 & 35 & MLG & CGK & 716.029 \\
\hline 18 & SRG & CGK & 1.838 .455 & & & & \\
\hline
\end{tabular}

\section{Kesimpulan}

Berdasarkan hasil analisis dapat disimpulkan bahwa tingkat uji kesesuaian matriks, model Model DCGR dengan fungsi hambatan tanner memiliki nilai standar deviasi lebih kecil dibandingkan dengan fungsi hambatan Eksponensial-negatif dan pangkat. Sehingga Model DCGR dengan fungsi hambatan tanner yang berarti lebih akurat jika dibandingkan dengan model DCGR dengan dengan fungsi habatan lainnya

Distribusi pergerakan penumpang tahun 2025 yang diramalkan dengan model gravity dengan batasan bangkitan dan tarikan (double constrain/DCGR) dapat dihasilkan seperti pada tabel 20.

\section{Ucapan Terimakasih}

Penulis mengucapkan banyak terima kasih kepada STTA yang telah memberikan dukungan finansial terhadap penelitian ini melalui Program Penelitian Tahun 2018.

\section{Daftar Pustaka}

[1] Tamin, O. Z. (2000). Perencanaan dan pemodelan transportasi. Penerbit ITB.

[2] Pratiwi, D. A., \& Hidayati, N. (2016). Model Distribusi Perjalanan Penumpang Domestik di Bandara Internasional Adi Soemarmo(Doctoral dissertation, Universitas Muhammadiyah Surakarta).

[3] Gaus, A. (2016). Estimasi Distribusi Pergerakan Arus Lalu Lintas Di Kota Ternate Dengan Menggunakan Metode Detroit. SIPIL SAINS, 2(4). 
[4] Gunawan, G., \& Medianto, R. (2016). Analisis Konektivitas Jaringan Transportasi Udara Nasional. Angkasa: Jurnal Ilmiah Bidang Teknologi, 8(2), 99-110.

[5] Gunawan, G., \& Medianto, R. (2017, January). Pemodelan Simulasi Jaringan Transportasi Udara Nasional. In Prosiding Seminar Nasional ReTII.

[6] Algifari. (2000). Analisis Regresi, Teori, Kasus \& Solusi. BPFE UGM. Yogyakarta.

[7] Tamin, O. Z. (2008). Perencanaan, Pemodelan dan Rekayasa Transportasi. Bandung: ITB.

[8] Black, J. (2018). Urban transport planning: Theory and practice. Routledge.

[9] Miro, F. (2005). Perencanaan transportasi: untuk mahasiswa, perencana, dan praktisi. Penerbit Erlangga. 